\title{
ENGLISH FOR TEP LEARNING MEDIA BASED VI-LEARN TO TRAIN VERBAL COMMUNICATION SKILLS OF CHEMISTRY STUDENT
}

\author{
Bertha Yonata ${ }^{1}$, Maria Monica SBW $^{1}$., Dian Novita ${ }^{1}$ \\ ${ }^{1}$ Jurusan Kimia, FMIPA, Universitas Negeri Surabaya \\ berthayonta@unesa.ac.id.
}

\begin{abstract}
Learning can not only be done in the classroom with direct face-to-face activities but can now be done with the help of IT, for example with learned learning. Although learning with vi-learn or e-learn cannot indeed replace overall face-to-face learning in the classroom. The world of education cannot be separated from technological advances such as this study because sometimes in carrying out classroom learning there are obstacles that cannot be avoided. These obstacles can be administrative in nature such as national holidays which coincide with the schedule of courses and cannot be replaced on another day due to limited space and insufficient time. In this study, learning tools for the English for TEP-based learning program have been developed to learn the verbal communication skills of students majoring in chemistry. From the data from the validation results, it can be concluded that learning devices consisting of enrichment modules and worksheets are feasible to be used in learning lessons. Likewise, from the response data, students showed a positive response from students in using enrichment modules and worksheets.
\end{abstract}

Keyword: learning media, Chemistry Student, verbal communication

\section{PENDAHULUAN}

Komunikasi merupakan cara makhluk hidup dalam menyampaikan informasi dari satu individu ke individu lain. Demikian pula dengan manusia yang menggunakan komunikasi untuk dapat menyampaikan atau meneruskan informasi ke individu yang lain. Manusia memiliki berbagai jenis komunikasi baik dalam bentuk tulis, lisan, maupun isyarat/simbol. Manusia dengan rasa ingin tahu yang besar mencoba menemukan cara, metode, dan instrumen yang dapat mempercepat pemindahan informasi dan memperluas jangkauan penyebaran informasi. Hal ini terwujudkan dengan semakin canggihnya alat atau media penyampai informasi, misalnya komputer dan internet.

Komputer dan internet inilah yang kemudian menjadi media atau bahkan sumber belajar yang paling efisien dan praktis digunakan pada saat ini. Dunia pendidikan telah bergeser dari pembelajaran tatap muka di kelas menjadi pembelajaran berbasis teknologi informasi yang dapat menyelesaikan permasalahan ruang dan waktu. Salah satunya adalah dengan dikembangkannya e-learning. Elearning merupakan bagian dari distance learning. Distance learning was defined as structured learning that takes place without the physical presence of the instructor [1]. Berdasarkan peraturan Rektor Universitas Negeri Surabaya Nomor: 005 Tahun 2017 tentang pedoman penyelenggaraan e-learning menyatakan bahwa E-learning adalah proses pembelajaran dengan menggabungkan prinsip-prinsip dalam proses pembelajaran dengan memanfaatkan teknologi informasi dan komunikasi serta multimedia [2]. 
Salah satu pengembangan e-learning lebih lanjut adalah Vi -learn. Seperti halnya e-learning atauapun dstance learning lainnya, vi-learn dapat diakses dimana saja baik menggunakan laptop/komputer maupun telepon genggam berbasis android selama dapat terhubung melalui jaringan internet. Selama ini mahasiswa sangat paham betul dalam menggunakan perangkat lunak yang tersedia di telepon genggam mereka. Sehingga vi-learn sebenarnya sangat cocok digunakan apabila mahasiswa dan dosen terkendala untuk mengadakan tatap muka di kelas. Seperti halnya ketika melaksanakan pembelajaran mata kuliah English for TEP yang merupakan mata kuliah institusi.

Berdasarkan buku panduan mahasiswa tahun 2017 disampaikan bahwa syarat kelulusan bagi mahasiswa non jurusan Bahasa Inggris adalah memiliki nilai TEP minimal 425. Bahasa Inggris merupakan salah satu dari beberapa bahasa PBB yang digunakan sebagai media komunikasi internasional. Oleh karena itu bahasa yang digunakan para kimiawan dalam menyampaikan hasil penelitiannya baik berupa artikel maupun buku teks adalah dalam Bahasa Inggris. Sehingga Bahasa Inggris haruslah menjadi keterampilan berkomunikasi bagi akademisi, tidak terkecuali bagi mahasiswa.

Berdasarkan hasil penelitian Yonata Keterampilan berkomunikasi tidak dapat hanya dilatihkan dalam beberapa tatap muka perkuliahan terutama berkomunikasi dalam Bahasa Inggris [3]. Oleh karena itu dengan mengembangkan perangkat pembelajaran English for TEP berbasis $\mathrm{Vi}$ Learn untuk melatih keterampilan berkomunikasi verbal mahasiswa Jurusan Kimia

Bagaimana kelayakan perangkat pembelajaran English for TEP berbasis ViLearn untuk melatih keterampilan berkomunikasi verbal mahasiswa Jurusan
Kimia dari aspek validitas teoritis dan validitas empiris?

\section{METODE}

Obyek dalam penelitian ini adalah perangkat pembelajaran English for TEP berbasis Vi-Learn untuk melatih keterampilan berkomunikasi verbal mahasiswa Jurusan Kimia

Waktu pelaksanaan penelitian adalah selama 8 bulan mulai April hingga Desember 2018 berlokasi di Jurusan Kimia FMIPA Unesa. Perangkat pembelajaran English for TEP berbasis Vi-Learn untuk melatih keterampilan berkomunikasi verbal mahasiswa Jurusan Kimia ini mengikuti alur model pengembangan yang disarankan oleh Thiagarajan, Semmel, dan Semmel [4] yaitu 4-D (four D Models). Model ini terdiri dari 4 tahap pengembangan yaitu Define, Design, Develop, dan Disseminate, namun dalam penelitian ini dibatasi sampai tahap develop.

Teknik analisis data dilakukan secara deskriptif kuantitatif perangkat pembelajaran English for TEP berbasis ViLearn dikatakan layak bila persentase lebih dari $61 \%$ [5].

1. Lembar Penilaian Dosen Ahli

Data penilaian dosen ahli ini diberikan pada proses penilaian perangkat pembelajaran English for TEP berbasis ViLearn dan hasilnya akan dianalisis secara deskriptif kuantitatif. Untuk menghitung persentase penilaian dari tiap aspek, rumus yang digunakan adalah sebagai berikut:

$$
\mathrm{K}=\frac{\mathrm{F}}{\mathrm{N} \times \mathrm{R}} \times 100 \%
$$

Keterangan : $\mathrm{K}=$ Persentase penilaian

$\mathrm{F}=$ Jumlah jawaban responden

$\mathrm{N}=$ Skor tertinggi dalam angket

$\mathrm{R}=$ Jumlah responden (adaptasi dari [5])

Dikatakan layak jika dari semua aspek dalam angket mendapatkan persentase 
$>61 \%$ dengan kriteria layak dan sangat layak.

2. Analisis Data Tes

Nilai tes keterampilan berkomunikasi verbal mahasiswa yang diperoleh dari posttest kemampuan structure and written expression dianalisis menggunakan sistem persentase dengan rumus sebagai berikut:

$$
=\frac{\text { skor yang diperoleh }}{\text { skor maksimal }} \times 100
$$

Pengembangan ini dikatakan layak jika $70 \%$ mahasiswa memperoleh nilai 70 .

3. Analisis angket respon mahasiswa

Hasil angket respon mahasiswa dianalisis dengan statistik deskriptif. Data dari angket respon mahasiswa mengenai perangkat pembelajaran English for TEP berbasis Vi-Learn dianalisis dengan menjumlahkan penilaian mahasiswa kemudian menghitung nilai rata-rata. Penilaian ya (skor 1) dan tidak (skor 0). Angket mahasiswa dikatakan berpemdapat positif jika rerata angket $>61 \%$

\section{HASIL DAN PEMBAHASAN \\ Tahap Pendefinisian (Define)}

Komunikasi sebagai bagian terpenting dalam kehidupan bermasyarakat merupakan salah satu poin dalam penelitian ini. Pada analisis ujung depan diperoleh beberapa permasalahan yang dihadapi antara lain tantangan penggunaan vi-learn sebagai bagian dari perkuliahan dan kemampuan mahasiswa jurusan kimia berkomunikasi dalam Bahasa Inggris verbal tulis.

Mata kuliah Bahasa Inggris merupakan mata kuliah institusi yang harus diprogram oleh mahasiswa. Berdasarkan kurikulum di Prodi S1 Kimia dan S1 Pendidikan Kimia, Mata kuliah Bahasa Inggris diprogram mahasiswa di semester 1. Pada penelelitian ini, uji coba terbatas diterapkan kepada mahasiswa prodi S1 Kimia angkatan 2018 yang memprogram mata kuliah Bahasa Inggris.

Analisis tugas yang dilakukan mahasiswa pada uji coba terbatasa adalah:

a. Membaca materi structure dalam Bahasa Inggris di Vi learn

b. Berlatih mengerjakan structure menggunakan Buku Bahasa Inggris

c. Mengerjakan worksheet, menunjukkan keterampilan berkomunikasi verbal tulis

Indikator hasil belajar akan menjadi dasar untuk penyusunan modul pengayaan dan worksheet. Indikator hasil belajar diturunkan dari kompetensi dasar mata kuliah English for TEP.

\section{Tahap Perancangan (design)}

Pada tahap ini dilakukan penyusunan pretest dan posttest. Pretest dan Posttest yang telah disusun terdiri dari structure and written expression.

Selain soal pretest dan posttest, pada tahap perancangan ini juga disusun Modul pengayaan untuk structure and written expression yang terbagi menjadi 18 bab. Penyusunan soal pretest dan posttest serta modul pengayaan untuk structure and written expression ini disebut desain 1. Desain 1 kemudian di telaah, disesuaikan dengan masukan dari penelaah.

Beberapa hal terkait masukan penelaah adalah mengenai tata tulis dan penambahan materi derajat kemungkinan (degree of certainty). Hasil revisi dari telaah kemudian disebut desain 2.

Hasil revisi dari masukan pada desain 1 kemudian disebut desain 2. Desain 2 kemudian divalidasi oleh dosen pengampu mata kuliah English For TEP dan diujicobakan kepada mahasiswa kelas Kimia B angkatan 2018.

Tahap Perancangan (design)

1. Penilaian Dosen Ahli

Desain 2 yang terdiri modul pengayaan pada kemampuan structure and written expression serta worksheet dinilai oleh 2 dosen pengampu mata kuliah English For TEP untuk didapakan nilai 
validasi. Penilaian dari para validator disajikan pada Tabel 1.

Tabel 1 Hasil Penilaian Kelayakan Modul Pengayaan Pada Kemampuan Structure And Written Expression Serta Worksheet Dari Dua Validator

\begin{tabular}{|c|c|}
\hline Aspek yang dinilai & $\%$ \\
\hline 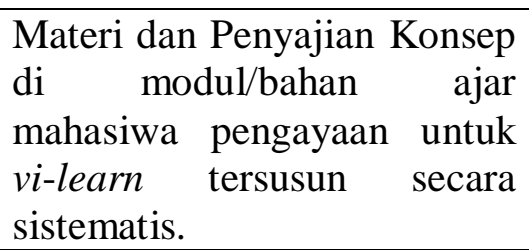 & 100 \\
\hline $\begin{array}{l}\text { Materi dan Penyajian Konsep } \\
\text { di modul/bahan ajar } \\
\text { mahasiwa pengayaan untuk } \\
\text { vi-learn sesuai dengan } \\
\text { indikator di RPS pada } \\
\text { kemampuan } \text { STRUCTURE } \\
\text { AND } \\
\text { EXPRESSION. }\end{array}$ & 100 \\
\hline $\begin{array}{l}\text { Materi dan Penyajian Konsep } \\
\text { di modul/bahan ajar } \\
\text { mahasiwa pengayaan untuk } \\
\text { vi-learn sesuai kaidah Bahasa } \\
\text { Inggris yang benar. }\end{array}$ & 75 \\
\hline $\begin{array}{l}\text { Penyajian tugas kinerja di } \\
\text { worksheet untuk vi-learn } \\
\text { dapat mendorong siswa } \\
\text { terlibat aktif } \\
\text { berkomunikasi verbal tulisan. }\end{array}$ & 87,5 \\
\hline $\begin{array}{l}\text { Materi dan Penyajian Konsep } \\
\text { di modul/bahan ajar } \\
\text { mahasiwa pengayaan untuk } \\
\text { vi-learn sesuai dengan tingkat } \\
\text { pengetahuan mahasiswa. }\end{array}$ & 87,5 \\
\hline 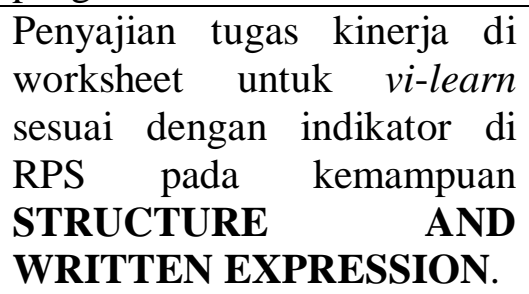 & 100 \\
\hline $\begin{array}{lr}\text { Kisi-kisi soal } & \text { sesuai dengan } \\
\text { indikator di } & \text { RPS pada } \\
\text { kemampuan } & \text { STRUCTURE } \\
\text { AND } & \text { WRITTEN } \\
\text { EXPRESSION } & \end{array}$ & 100 \\
\hline Angket respon mahasiswa & 87,5 \\
\hline
\end{tabular}

\begin{tabular}{|c|c|}
\hline Aspek yang dinilai & $\%$ \\
\hline $\begin{array}{l}\text { mencakup kesesuaian bahasa } \\
\text { dengan } \\
\text { mahasiswa. }\end{array}$ & \\
\hline $\begin{array}{lr}\text { Angket respon } & \text { mahasiswa } \\
\text { mencakup } & \text { kemampuan } \\
\text { mahasiswa } & \text { berkomunikasi } \\
\text { verbal tulisan } & \\
\end{array}$ & 87,5 \\
\hline $\begin{array}{l}\text { Angket respon mahasiswa } \\
\text { mengenai kemudahan } \\
\text { mahasiswa memahami isi } \\
\text { modul/bahan ajar mahasiswa } \\
\text { dan worksheet }\end{array}$ & 87,5 \\
\hline
\end{tabular}

Dari data yang tersaji pada Tabel 1 dapat diketahui bahwa modul pengayaan pada kemampuan structure and written expression serta worksheet layak digunakan sebagai bahan ajar dalam mata kuliah English for TEP berbasis Vi-learn.

Untuk aspek konstruks, Materi dan Penyajian Konsep di modul/bahan ajar mahasiwa pengayaan untuk vi-learn tersusun secara sistematis. Hal ini disebabkan pada modul pengayaan untuk kemampuan structure and written expression sudah disusun dalam bab (chapter). Terdapat 18 bab (chapter) dalam modul

Aspek isi dari modul pengayaan, worksheet serta kisi-kisi soal pada kemampuan structure and written expression sudah sesuai dengan indikator RPS mata kuliah English for TEP. Modul pengayaan dan worksheet pada kemampuan structure and written expression mengunakan Bahasa Inggris yang benar.

Terkait vi learn, berdasarkan hasil uji coba mengunggah berkas ke laman vi learn terbukti bahwa berkas mudah diunggah dan mudah untuk diunduh mahasiswa. Hal ini dikuatkan dari hasil wawancara dengan mahasiwa dan angket respon mahasiwa yang tersaji pada Tabel 2 .

Mahasiswa yang telah mengunggah tugasnya di laman vi learn akan muncul 
notifikasi. Data aktivitas login dapat dipantau. Setelah diunduh, kemudian pekerjaan mahasiswa dianalisis.

\section{Keterampilan Berkomunikasi Verbal Tulis}

Sejumlah 30 dari 32 mahasiswa mengikuti pretest dan posttest. Pretest dan posttes diberikan secara keseluruan meliputi keterampilan listening, structure and written expression, dan reading. Namun penelitian ini dibatasi pada keterampilan structure and written expression. Mahasiswa mengerjakan prestest tanggal 19 November 2018 kemudian mengerjakan tugas di worksheet yang terunggah di vi learn. Tugas dapat dikerjakan mahasiswa dengan membaca modul pengayaan yang sudah diunggah di vi learn. Mahasiswa memiliki waktu sekitar 7 hari sampai batas waktu pengumpulan tugas melalui vi learn. Penggunaan vi learn memiliki kelebihan yaitu mampu menjaga disiplin mahasiswa dalam mengerjakan dan mengumpulkan tugas. Setelah mengerjakan tugas di vi learn kemudian mahasiwa mendapat posttest yang dilaksanakan tanggal 26 November 2018.

Berkas jawaban mahasiwa dalam mengerjakan worksheet yang diunggah dalam vi learn kemudian diunduh untuk dianalisis.

\section{Tes Keterampilan Berkomunikasi Verbal}

Dari data menunjukan bahwa tidak ada mahasiswa yang tuntas pada pretest sedangkan pada posttest diperoleh $79 \%$ mahasiswa telah tuntas dengan memperoleh nilai 70 . Nilai pretest dan posttest ini untuk kemampuan structure and written expression mahasiswa.

Berdasarkan temuan pada kemampuan mahasiswa maka hasil penelitian sesuai dengan pendapat para ahli salah satunya Wittock (1987) dalam Slavin yang menyatakan bahwa jika suatu informasi ingin dipertahankan dalam memori, dan saling berkaitan dengan informasi sebelumnya yang tersimpan dalam memori, maka individu (dalam hal ini adalah mahasiwa) yang belajar (English for TEP) harus terlibat dalam pengaturan kembali kognitif atau elaborasi materi [6].

\section{Angket Respon Mahasiswa}

Mahasiswa diminta mengisi lembar angket repon untuk mengetahui pendapat mereka mengenai perangkat pembelajaran yang dikembangkan. Tabel 2 menyajikan persentase mahasiswa yang memberikan tanggapan positif (pada kolom "Ya") terhadap modul pengayaan dan worksheet English for TEP berbasis Vi Learn. Mahasiswa juga diminta memberikan saran dan menuliskan kendala pada kolom yang disediakan.

Tabel 2 Data Angket Respon Mahasiswa Terkait Pengembangan Perangkat Mata Kuliah English for TEP Berbasis Vi Learn

\begin{tabular}{|cl|c|}
\hline \multicolumn{2}{|c|}{ Aspek } & $\%$ Ya \\
\hline 1. & $\begin{array}{l}\text { Membangkitkan motivasi/ } \\
\text { minat/rasa ingin tahu. }\end{array}$ & 96,67 \\
\hline 2. & $\begin{array}{l}\text { Materi sesuai dengan taraf } \\
\text { berpikir Anda. }\end{array}$ & 73,33 \\
\hline 3. & Sistematika isi sesuai. & 96,67 \\
\hline 4. & Konten mutakhir. & 90,00 \\
\hline 5. & $\begin{array}{l}\text { Menggunakan bahasa Inggris } \\
\text { yang mudah dipahami. }\end{array}$ & 86,67 \\
\hline 6. & $\begin{array}{l}\text { Istilah yang digunakan tepat } \\
\text { dan dapat dipahami }\end{array}$ & 90,00 \\
\hline 7. & $\begin{array}{l}\text { Menggunakan istilah dan } \\
\text { simbol secara ajeg. }\end{array}$ & 93,33 \\
\hline 8. & $\begin{array}{l}\text { Stuktur kalimat dengan bahasa } \\
\text { yang digunakan sesuai. }\end{array}$ & 93,33 \\
\hline 9. & $\begin{array}{l}\text { Penyajian materi lugas (tidak } \\
\text { bertele-tele). }\end{array}$ & 93,33 \\
\hline 10. & $\begin{array}{l}\text { Modul pengayaan English for } \\
\text { TEP Worksheet dan } \\
\text { membantu anda } \\
\text { menyampaikan ide melalui } \\
\text { tulisan dalam Bahasa Inggris. }\end{array}$ & 90,00 \\
\hline 11. $\begin{array}{l}\text { Penggunaan vi-learn di SSO } \\
\text { Unesa mudah dioperasikan }\end{array}$ & 86,67 \\
\hline
\end{tabular}


Berdasarkan data angket respon mahasiswa pada Tabel 2 dapat disimpulkan bahwa mahasiswa setuju materi pada modul pengayaan English for TEP mampu membantu dalam memahami materi. Meskipun demikian ternyata mahasiswa juga memberikan argument mengapa aspek kedua mengenai kesesuaian materi dengan taraf berpikir mahasiswa masih dianggap tiak sesuai. Tanggapan dari mahasiswa adalah berkaitan dengan sulitnya mereka memahami vocabulary di bab (chapter) yang disajikan di tiap pertemuannya.

Berkaitan dengan penggunaan vi learn di SSO Unesa yang dirasa oleh 13,33\% mahasiswa (4 mahasiswa) masih sulit dioperasikan, hal ini dikarenakan beberapa mahasiswa belum disetujui KRS online oleh DPA pada saat di pertemuan awal kepenasehatan. Padahal pembentukan kelas vi learn ini sudah dilakukan peneliti di awal perkuliahan di semester gasal 2018/2019 sedangkan mahasiswa baru melaporkan kesulitannya kepada peneliti pada saat minggu terakhir pengumpulan tugas.

\section{SIMPULAN DAN SARAN}

Berdasarkan beberapa temuan yang telah tersaji di Bab V maka Modul pengayaan dan worksheet dapat disimpulkan layak digunakan sebagai perangkat pembelajaran pada mata kulaih English for TEP dari segi kelayakan teoritis dan kelayakan empiris. Simpulan ini didasarkan pada temuan:

Penilaian dari validator dari aspek kelayakan teoritis dalam kategori sangat layak dengan rentang penilaian $75 \%$ sampai $\quad 100 \%$. Keterampilan berkomunikasi verbal tulis mahasiwa dikatakan terlatih dilihat dari nilai ketuntasan mahasiwa di posttest telah mencapai lebih dari $70 \%$ mahasiswa tuntas. Kelayakan empiris juga didukung dengan respon positif mahasiswa dalam kategori sangat layak.

\section{UCAPAN TERIMA KASIH}

Penulis mengucapkan terima kasih pada Fakultas Matematika dan Ilmu Pengetahuan Alam Universitas Negeris Surabaya melalui dana penilitian PNBP 2018

\section{DAFTAR PUSTAKA}

[1] Holden, Jolly T; and Westfall, Philip JL. 2009. An Instructional Media Selection Guide for Distance Learning. USDLA

[2] Peraturan Rektor Universitas Negeri Surabaya nomor : 005 tahun 2017 tentang pedoman penyelenggaraan $\mathrm{E}$ Learning.

[3] Yonata, Bertha. 2014. Keterampilan Komunikasi Mahasiswa Pendidikan Kimia Unggulan 2013 dalam Bahasa Inggris Pada Materi Kimia Dalam Pembelajaran Kooperatif. Prosiding Seminar Nasional Kimia, ISBN : 978-602-0951-00-3 Jurusan Kimia FMIPA Universitas Negeri Surabaya, 20 September 2014

[4] Muslimin, Ibrahim. 2001. Model Pengembangan Perangkat Pembelajaran Menurut Jerold E. Kemp \& Thiagarajan. Surabaya: Unesa Press

[5] Riduwan. 2005. Skala Pengukuran Variabel-Variabel Penelitian.

Bandung: Alfabeta.

[6] Slavin, R.E. 1997. Educational Psychology Theory and Practice. Fifth Edition. Boston: Allyn and Bacon. 
Vol. 2, No. 2, December 2018 (70-75) 